\title{
UNLIKELY SCENARIO: HALT OF IRANIAN NUCLEAR PROGRAMME
}

\author{
Res. Assist. İrem AŞKAR KARAKIR, Dokuz Eylül University, Faculty of Business, \\ Department of International Relations, irem.askar@deu.edu.tr \\ Assoc. Prof. Dr. Nilüfer KARACASULU, Dokuz Eylül University, Faculty of \\ Business, Department of International Relations, nilufer.karaca@deu.edu.tr
}

\begin{abstract}
This article analyzes if a change in domestic political dynamics might lead to a change of attitude toward abandoning Iranian nuclear programme, focusing on the attitudes of Iranian political factions, namely radical conservatives, pragmatic conservatives and reformists toward the Iranian nuclear programme. Presently, there is a common agreement among the political factions on how to continue on nuclear programme. Though this difference among attitudes is known, there has not been much literature on this issue. The article aims to show that even though there might be a change in the inner political dynamics, it would be a mistake to expect a great change in the official policy of Iran on nuclear programme. Iran will not halt its nuclear programme. The article argues that with the re-election of Mahmoud Ahmedinejad in the June 2009 presidential elections, in the short-term, there will not be any change in Iran's official attitude regarding its nuclear programme. Besides in the long-term, it is underlined that even if Ahmedinejad administration might be replaced by 'reformists', Iran will not abandon its aim to achieve nuclear power, only there may be moderation in Iran's official rhetoric, and negotiations with the international community might improve.
\end{abstract}

Key Words: Iran's nuclear programme, Iranian domestic politics, political factions in Iran

\section{INTRODUCTION}

This article is concerned whether there is a difference on foreign policy approaches of 'conservative' Mahmoud Ahmadinejad and 'reformist' MirHossein Mousavi, which might lead to a change in official policy on nuclear issue. Initially, Iran's political structure with a special emphasis on priorities, policies and foreign policy orientations of different political factions including 
hardliner conservatives, pragmatic conservatives and reformists is reviewed. Yet, the main focus of the article is on the attitudes of separate political factions to the Iranian nuclear programme.

Iran's nuclear programme is important, because particularly the United States (US) and its close ally Israel felt threatened. Also, a nuclear Iran might change the balance of power in the Middle East. Thus, international concern on Iran's nuclear activity has continuously increased following the presidential election of Mahmoud Ahmedinejad in 2005. Especially, uncompromising rhetoric of Ahmedinejad has been influential in bringing negotiations between Iran and the international community to a deadlock. Since 2005, Iran has been rejecting international community's demand to suspend its nuclear enrichment, arguing for the peaceful intentions of its nuclear programme.

However, during Muhammad Khatami's presidency in November 2004, Iran and the European Union (EU) - notably France, Germany and the United Kingdom (UK), abbreviated as the EU-3- signed the Paris agreement, which encouraged the suspension of Iran's nuclear programme in exchange for intensified economic relations between the EU and Iran. Yet, in the immediate aftermath of Ahmadinejad's presidency, deterioration of relations with the EU/EU3 was observed, since the Ahmedinejad administration refused to restart negotiations with the EU/EU3. (BBC News, http://news.bbc.co.uk/go/pr/fr/-/2/hi/middle_east 17279852.stm, 10/03/2008). The new administration carried on its uranium enrichment programme, which had been suspended for nine months during the negotiations. Moreover, the Ahmedinejad administration adopted a confrontational attitude toward the EU, the International Atomic Energy Agency (IAEA) and the US on the nuclear issue, rejecting an incentive package proposed by the EU. (Kamrava, 2007; 96)

In May 2008, with a new proposal for 'Constructive Negotiations', Iran demonstrated its readiness to restart negotiations on the condition that it would continue its uranium enrichment. On 14 June 2008, the EU High Representative, Javier Solana presented a counter proposal (Institute for Science and International Security, http://www.isis-online.org /publications/iran/Diplomatic_Offer_16June2008.pdf, 20/06/ 2008) to Iran, on behalf of the United Nations Security Council (UNSC) permanent members France, the UK, Russia, China and the US - plus Germany, to restart negotiations. The new package involved previous proposals presented to Iran in June 2006 (UN Security Council Report, http://www.securitycouncil report.org/atf/cf/\%7B65BFCF9B-6D27-4E9C-8CD3-

CF6E4FF96FF9\%7D//ran\%20S2006521.pdf, 12/02/2008). It was repeated that talks might start about a long-term agreement on Iran's nuclear programme if Iran halts uranium enrichment. Tehran stated that they will consider the proposals, but indicated no specific time when they will reply on this issue. Besides, Tehran announced that Iran has been waiting for an official response to its own proposed offer. 
At present, the negotiations between Iran and the international community are at stalemate. With Ahmedinejad's reelection, this article argues that there would be no modification in Iran's attitude toward negotiations in the short-term, even though the US newly elected President Obama is more open to starting a dialogue then the previous US administration. What about the long-term? An administration change in favour of 'reformists' might lead to a moderation in Iran's attitude on negotiations while also improving Iran's relations with the international community; yet, even reformists might be in power, it would be misleading to expect Iran to abandon its nuclear programme.

\section{BRIEF REVIEW OF DOMESTIC POLITICAL TERMINOLOGY}

Iranian political administrative structure consists of both elected and unelected individuals and institutions. Elected political institutions include the president, cabinet, parliament and assembly of experts. Unelected political institutions include the supreme leader (Velayet-e Faqih / Rule of the Jurisprudent), armed forces, head of judiciary, expediency council and guardian council. Thus, the Islamic Republic empowers the Iranian population to elect some individuals and institutions, while other individuals and institutions are empowered with the ultimate authority over national affairs without any electoral process. (Takeyh, 2003a; 43) As Bahgat (2006; 321-322) points out, "True, the Supreme Leader Ayatollah Khamenei had the final word on all important issues, but it is also true that the system was designed to ensure a level of checks and balances between different institutions."

Furthermore, there are three main factions within the Iranian political system: hardliner conservatives, pragmatic conservatives, and reformists. Each of these factions has its own agendas, priorities and positions with respect to foreign policy issues. Thus, on the one side of the political scene stand conservatives, whereas on the other side stand reformists. Furthermore, conservatives do not constitute a uniform bloc. They are also divided among themselves as hardliners and pragmatics, hardliners being more associated with Ahmedinejad while pragmatics are associated with Ali Akbar Hashemi Rafsanjani.

With Ahmadinejad's presidency, political power of hardliner conservatives has been consolidated. The victory of Ahmadinejad owed largely to his deployment of a populist rhetoric emphasizing social justice, independence, and export of the revolution. Ahmadinejad's presidency implied "the rise of new political elite of 'neoconservatives' with a new political discourse and a new agenda." (Ehteshami and Zweiri, 2007; 73)

Here on we will briefly review differences of the three factions. 


\subsection{Hardliner Conservative}

Firstly, we will explain what hardliner conservative means in Iran. With respect to domestic politics, hardliner conservatives emphasize promotion of justice through the Islamic values and principles. Issues such as civil society, women's rights and human rights are irrelevant for hardliner conservatives. Instead, they advocate strict interpretation of Islam in the name of cultural purification to protect Iran's Islamic culture from the Western influence. (Seifzadeh, 2003; 63) They are also in favour of state involvement in cultural and social issues, and do not avoid using harsh means to endorse their cultural ideals and traditional values. For instance, they support the view that women should dress in accordance with the Islamic values and mobilize all means to ensure it.

Furthermore, hardliners follow an anti-Western rhetoric pointing out corruptness of the Western culture. They make frequent references to importance of selfsufficiency, particularly in the scientific and technological fields to consolidate Iranian position in the international system. They consider the West as the major obstacle to Iranian scientific and technological advancement claiming that the EU and the IAEA are both 'bullies' to impede Iran's progress. (Kamrava, 2007; 96-97) Hardliners view 1979 Islamic Revolution more as anti-Western, antiimperialist and anti-US uprising, rather than anti-monarchical. Since hardliners are passionate advocates and guardians of the Islamic Revolution, they have established a positive correlation between protecting the Republic's national interests and confronting the West. A hardliner conservative, Ayatollah Mahmood Hashemi Shahroudi, the chief of the judiciary, stated in 2001, "Our national interests lie with antagonizing the Great Satan. We condemn any cowardly stance toward America and any word on compromise with the Great Satan." (Pollack, 2006; 22)

For example, Ahmadinejad has continuously accused the Western countries for attempting to prevent Iran from developing peaceful nuclear energy. He continuously stated that Iran would never give up developing nuclear technology. He even threatened to block supply of oil, therefore, causing a radical increase of oil prices. He charged the UN Security Council as being a tool to realize the Western interests. He said that the latest UN resolution (2008) would further "downgrade the UN's standing" since the Security Council has taken anti-Iran decisions based on false information. (Tehran Times, http://www.tehrantimes.com/NCms/2007.asp ?code=164434, 10/03/2008). Similarly, the former Majlis Speaker Gholam-Ali Haddad-Adel criticized the UN Security Council's move to intensify sanctions against Iran as "illogical, illegal, and absolutely political." (Tehran Times, http://www.tehrantimes.com/NCms/2007.asp ?code=164434, 10/03/2008).

In addition, regarding foreign policy, hardliners use 'conflict ridden rhetoric' as a means to achieve their goals. Chubin (2006; 33) points out that hardliners view the world as a Hobbesian one. They believe that negotiations and compromises would only contribute to preserving the status quo in foreign relations. Thus, 
they advocate conflict and contention in order to extend influence of the regime beyond its borders. They are also well aware that existence of a foreign threat has a unifying and mobilizing impact on the public. Presence of an external threat has helped hardliners "to divert attention from their inadequate domestic record". (Chubin, 2002; 110) To put it differently, they have made use of conflict and confrontation ridden rhetoric to cover the shortcomings of their policies, both in the political and socio-economic fields. Thus, the primary beneficiary of US hostility and sanctions policy has been hardliners, as isolation from the international community has helped them justifying their political power. (Takeyh, 2003a; 55)

\subsection{Pragmatic Conservative}

In this section, the meaning of pragmatic conservatism in Iran is explained. Ali Akbar Hashemi Rafsanjani (president between 1989-1997), who is an influential figure in the Iranian political system, is the main representative of pragmatic conservatives. Ali Larijani, who is the former National Security Council chairman and the current speaker of the Iranian Parliament, and Mohammed Baqr Qalibaf, who is the current popular mayor of Tehran and the former national police chief, are also outstanding figures of pragmatic conservatives. What especially distinguish pragmatic conservatives from hardliner conservatives are their apparent pragmatic attitude and emphasis on economic issues. Pragmatic conservatives prioritise economic issues both in their domestic and foreign policy agendas. They are strong advocates of economic reform and shape their policies and strategies in accordance with their priorities in the economic field. As Takeyh and Gvosdev $(2005 ; 38)$ notes "pragmatic conservatives have been critical both of reformists and hardliners for failing to take adequate steps to deal with concrete problems" particularly in the economic realm.

Yet, pragmatic conservatives do not concentrate on social and political freedoms. Their advocacy for liberalization is limited to only economic issues. Traditionally, they have followed a conservative line when the social and cultural issues are in focus. However, it would be appropriate to state that pragmatics have adopted a much less radical discourse on social and cultural issues when compared with hardliners.

For instance, during his presidency between the years 1989-1997, Rafsanjani followed a pragmatic policy concentrating on development of foreign trade relations and liberalization of Iranian economy. He also encouraged rapprochement with the West. Rafsanjani and his followers have long prioritized rebuilding Iran's economy, recognizing that this required closer relations with the Western states to stimulate trade and investment in Iran. (Pollack, 2006; 7576) Even, they have made alliances with reformists whenever their interests converged. (Seifzadeh, 2003; 61)

In foreign policy, pragmatic conservatives aim at ending Iran's isolation in international markets and to develop economic relations with other states. To 
do this, they state that Iran has to engage with not only international actors such as the EU but also with its neighbours. (Takeyh and Gvosdev, 2005; 37) Overall, it is fair to suggest that pragmatics have followed a flexible foreign policy from time to time, establishing tactical compromises with the West to ensure Iran's economic development.

\subsection{Reformist}

Lastly, we will explain what reformist means in Iran. Reformist faction is primarily identified with Muhammad Reza Khatami, who was president for two terms, 1997-2005, and Mir-Hossein Mousavi, who is the former and the last Prime Minister of Iran and a popular candidate for presidency in June 2009 elections. (Gasiorovski, 2007; 127) During the two terms when they held key governmental positions under the Khatami's administration, reformists have succeeded in limited political liberalization. This was probably due to the fact that conservatives have occupied key unelected political positions. This led to a disappointment among many Iranians, who believed that reformists would realize political and socio-economic reforms in line with their promises.

Reformists prioritize pluralism and freedoms in political, social and cultural fields. They have underlined the significance of democratic values such as liberal principles of freedom of expression and tolerance. Accordingly, they have advocated social, cultural and political reform including political rights, free functioning of the civil society, freedom of speech, freedom of the media and women's rights. Unlike hardliners, reformists do not focus on the way women dress or behave. Instead, they oppose state involvement in cultural and social issues, and search for the removal of social and cultural restrictions.

With respect to foreign policy, reformists adopt a moderate discourse in line with principles of cooperation and dialogue with the West and regional states. They have encouraged constructive diplomatic relations with the other states. Particularly during the mid-1990s, Khatami intensively "endorsed a foreign policy of engagement and integration in the global society". (Takeyh, 2003b; 2526) In this regard, Khatami opposed to Samuel Huntington's (1993) 'Clash of Civilizations' thesis, arguing for a 'Dialogue Among Civilizations.' (Ramazani, 1998; 181)

Overall, reformists have paid particular attention to political liberalization and reforms in social and cultural fields. They also emphasized establishing good relations with the West. Indeed, as Pollack (2006; 75) points out "during the Khatami administration, many leading Iranian reformists privately assured the US that Mr. Khatami would be willing to give up the nuclear programme altogether as part of a general rapprochement." The Khatami administration can be considered somewhat successful in reducing Iran's global economic isolation and attracting foreign investment since there was a dialogue with the EU for improving mutual relations. (Kamrava, 2007; 95) 


\section{ATTITUDES OF FACTIONS ON THE NUCLEAR PROGRAMME}

There is general agreement among the three different political factions that it is Iran's right to continue its nuclear programme for peaceful purposes. However, there is divergence among them on both how to achieve nuclear energy and how to handle negotiations with the international community. As Kamrava points out; these political factions "agree that Iran must have access to nuclear technology, what they disagree over is the means to achieving this end or, more accurately, the price they are willing to pay in order to accomplish the same goal". (Kamrava, 2007; 95)

While holding office, each of the political factions expressed their approval for possessing nuclear technology, and linked it directly to Iran's national interest, particularly emphasizing the importance of generating nuclear energy for Iran's domestic energy needs. What differentiated these factions is that whereas reformists and pragmatic conservatives are willing to negotiate with the international community on the nuclear activity, hardliner conservatives are impatient to achieve nuclear technology and disregard the attitude of the international community. In Takeyh's (2003b; 25) words, hardliners are more willing to "violate Iran's treaty commitments and imperil important regional relationships for the sake of acquiring nuclear power," when compared with either pragmatic conservatives or reformists. They are more suspicious about the West in general and the US in particular, in comparison with the other two factions. As a result, unlike two other factions, hardliners are unwilling to negotiate with the international community on the nuclear programme.

Furthermore, even though both conservative factions converge on the desire to enhance Iran's power and influence by means of nuclear technology, they differ on their perceptions of Iran. While pragmatic conservatives have a realistic perception of Iran, hardliners have overestimated Iran's power and centrality in the international system, exaggerated the Western antagonism and hostility toward Iran. (Chubin, 2006; 34) In this regard, pragmatic conservatives concern about potential costs such as isolation and sanctions, whereas hardliner conservatives usually remain to be indifferent to potential costs. For example, Ahmadinejad's bold statements have demonstrated indifference and disrespect of hardliners for the international community. Hardliners view the nuclear programme as the ultimate guarantor of Iran's influence and security. (Chubin and Litwak, 2003; 106)

Hardliners believe that access to nuclear technology would offer an unmatched opportunity to prevent any intervention into Iran's domestic affairs particularly by the Western powers. In addition, they also assume that nuclear technology would strengthen Iran's bargaining power in regional and international interactions. Thus, they have emphasized the significance of nuclear technology to preserve security and prestige of the Republic, believing that possession of 
nuclear capability would make Iran immune from any external interference into its domestic affairs such as human rights.

On the other hand, pragmatic conservatives have not approved the attitude of Ahmadinejad and his followers on the nuclear issue. Pragmatic conservatives focus on the critical connection between nuclear confrontation with the West and domestic economic concerns. They mainly concentrate on the impact of nuclear activity on domestic economy. (Pollack, 2006; 75) In this regard, they have supported the nuclear programme as long as it did not have a negative impact on foreign trade relations and domestic economy. They have frequently highlighted that they would even suspend the nuclear programme temporarily in order to improve economic relations with the West. (Pollack, 2006; 75-76) For example, Rafsanjani has repeatedly emphasized that Iran was ready to negotiate with the international community. Likewise, pragmatic conservatives believe that given the fact that the US has been highly critical and suspicious of Iran's nuclear programme, any provoking act of Iran would lead other states to accept US attitude, thus leading to Iran's further isolation. In this regard, prior to referral of Iran to the UN Security Council, Rafsanjani criticized Ahmadinejad administration's provocative strategies and instead argued in favour of intense diplomacy. (Chubin, 2006; 34-35)

Furthermore, as pragmatic conservatives have prioritized economic efficiency, they are aware that imposition of multilateral sanctions would put Iranian economy under constraint. For pragmatic conservatives, harmonious relations with foreign states are required for increasing foreign investment and trade. (Pollack and Takeyh, 2005; 23) Thus, pragmatic conservatives have not approved hardliners' aggressive attitude, which might lead to isolation and increasing sanctions on Iran. In short, pragmatic conservatives have opposed each and every act, which have raised difficulties for Iran's economic integration into the global economy.

On the other hand, reformists are much more concerned about relations with the international community than the other factions, and thus during the Khatami administration they accepted to sign the Additional Protocol of the Nuclear NonProliferation Treaty (NPT). Furthermore, despite pressures by hardliners for discarding the NPT, the Khatami administration signed the Additional Protocol with the IAEA prior to the Iranian consent for freezing its uranium enrichment activities. (Pollack and Takeyh, 2005; 22) Their awareness of the potential costs of disruption of relations with the international community also forced reformists to suspension of the enrichment programme through signing the Paris agreement in November 2004. The Paris agreement was the fruit of negotiations between the reformist administration and the EU/EU-3, and it was a clear indication that reformists prefer cooperation. Following these two constructive moves by reformists, Iran had been rewarded by economic incentives. 
These two moves by reformists are also meaningful to demonstrate the extent of reformists' willingness to act in harmony with the international community. According to Chubin $(2006 ; 31)$, reformists generally view the nuclear programme as one among other several technologies and they are not willing to lead to "Iran's estrangement from the international community and hurt relations with neighbours". When they were in power, they underlined significance of dialogue and cooperation with the international community. As Kamrava (2007; 96) indicates,

Keen to lower tensions and to show the country's willingness to cooperate with the EU and IAEA, when the reformists were in power, they were willing to suspend enrichment for the life of the negotiations and were eager to come up with a win-win compromise whereby Iran would continues its nuclear activities under a presumably toughened IAEA inspection regime.

Table 1: Political Factions in Iran

\begin{tabular}{|c|l|l|l|}
\hline Hardliner & $\begin{array}{l}\text { Domestic Policy } \\
\text { Priorities }\end{array}$ & $\begin{array}{l}\text { Foreign Policy } \\
\text { Orientations }\end{array}$ & $\begin{array}{c}\text { Nuclear } \\
\text { Programme }\end{array}$ \\
\hline Conservatives & $\begin{array}{l}\text { Emphasis on the } \\
\text { justice through } \\
\text { Islamic values } \\
\text { and principles. }\end{array}$ & $\begin{array}{l}\text { Radical foreign } \\
\text { policy. } \\
\text { Confrontation with } \\
\text { the West } \\
\text { particularly, the US. }\end{array}$ & $\begin{array}{l}\text { Unwilling to } \\
\text { negotiate with } \\
\text { the international } \\
\text { community on } \\
\text { the nuclear } \\
\text { activity. }\end{array}$ \\
\hline Pragmatic & $\begin{array}{l}\text { Emphasis on } \\
\text { economic issues. } \\
\text { Advocate } \\
\text { economic reform. }\end{array}$ & $\begin{array}{l}\text { Flexible foreign } \\
\text { policy to } \\
\text { accomplish } \\
\text { economic interests. } \\
\text { Normalization of } \\
\text { foreign relations } \\
\text { with the West. }\end{array}$ & $\begin{array}{l}\text { Willing to } \\
\text { negotiate with } \\
\text { the international } \\
\text { community as } \\
\text { long as Iran's } \\
\text { economic } \\
\text { interests are } \\
\text { secured. }\end{array}$ \\
\hline \multirow{5}{*}{ Reformists } & $\begin{array}{l}\text { Emphasis on } \\
\text { social and } \\
\text { political reform } \\
\text { (political rights, } \\
\text { civil society, } \\
\text { freedom of } \\
\text { speech, freedom } \\
\text { of the media, } \\
\text { women's rights). }\end{array}$ & $\begin{array}{l}\text { Moderate foreign } \\
\text { policy. Cooperation } \\
\text { and dialogue with } \\
\text { the West and } \\
\text { regional states. }\end{array}$ & $\begin{array}{l}\text { Willing to } \\
\text { negotiate with } \\
\text { the international } \\
\text { community on } \\
\text { the nuclear } \\
\text { activity. }\end{array}$ \\
\hline
\end{tabular}

Yet, with the coming power of Ahmedinejad administration in 2005, Iran has restarted its uranium enrichment disregarding the Paris agreement and 
warnings of the international community. This act led to the implementation of further economic and diplomatic sanctions over Iran. Reformists have been accusing Ahmedinejad on Iran's economic and diplomatic isolation. Particularly, provocative speeches by Ahmadinejad and the approval of third set of sanctions by the UN Security Council in 2008 led to reformists' sharp criticism of hardliners. (Gasiorowski, 2007; 129-130) Muhammad al-Abtahi, a former vice president under Khatami's administration said; "On the nuclear issue, for instance, we believe that through dialogue we can have our rights [to nuclear technology] while also winning the world's trust. There has been nothing useful in getting three UN Security Council resolutions against us." (Economist, http://www.economist.com/displayStory.cfm?story_id=13331239, 25/03/ 2009).

\section{CONCLUSION}

Iran's nuclear programme has preserved its significance on world's political agenda since the early 2000s. Suspicion over Iran's nuclear intentions has led to an intensive search for settling the nuclear issue by the international community. The issue has become more complicated following Ahmedinejad's presidency in 2005 and by the time this article is written there is still a deadlock in negotiations among Iran and the international community. Access to nuclear capability has been one of the critical issues that have long been discussed within Iran's domestic political circles. Having analysed distinct attitudes of three factions towards Iran's nuclear programme, there are two conclusions to be made.

First of all, political factions in Iran have converged on the view that Iran has the right to have an access to nuclear technology for peaceful purposes. In this regard, none of these political factions have any consent for completely abandoning uranium enrichment activities. Yet, these political factions have diverged on how to manage this process since their attitudes differ with respect to negotiations with the international community on the nuclear issue. The principal difference among the attitudes of these political factions arises from their divergent foreign policy views. Here, the main distinction is between reformists who favour accommodation with the international community in settling the nuclear dispute and hardliner conservatives, who strongly oppose any accommodation with the international community. There are also pragmatic conservatives, who approve accommodation with the international community as long as it serves Iran's economic interests. In addition, it would be fair to maintain that reformists and pragmatic conservatives seem more sensitive to the costs of an uncompromising attitude in nuclear negotiations including tougher economic sanctions and diplomatic isolation.

Another conclusion is that the progress in settling Iran's nuclear dispute depends on which faction dominates the political regime. Since the election of Ahmadinejad for the first time in 2005 , hardliners have been more influential in determining the developments on the nuclear programme and Iran's attitude towards the international community. The Ahmadinejad administration has 
rejected any nuclear deal offered by the major world powers that demands a suspension of its uranium enrichment. They have even argued in favour of leaving the NPT to eliminate any barriers to nuclear activity. (Chubin, 2006; 29) Now that Ahmedinejad became successful in June 2009 presidential elections against his leading rival Mir-Hossein Mousavi from the reformist camp, it is unlikely to expect an improvement in nuclear negotiations.

Overall; this article argues that with the re-election of Ahmedinejad, in the short term there will not be any change in Iran's official attitude regarding its nuclear programme. A nuclear deal with the international community seems difficult as long as the Ahmedinejad administration sustains an uncompromising tone. Furthermore even in the long-term, it is underlined that even if the Ahmedinejad administration would be replaced by reformists, Iran will not abandon its aim to achieve nuclear power, only there may be moderation in Iran's official rhetoric and negotiations with the international community may improve.

\section{REFERENCES}

BAHGAT, G. (2006): "Nuclear Proliferation: The Islamic Republic of Iran", Iranian Studies, 39 (3): 307-327.

BBC NEWS (5 March 2008), "Iran Rejects New EU Nuclear Talks", http://news.bbc.co.uk/go/pr/fr/-/2/hi/middle_east/7279852.stm, (10.03. 2008).

CHUBIN, S. (2002): Whither Iran? Reform, Domestic Politics and National Security, New York, Oxford University Press.

CHUBIN, S. (2006): Iran's Nuclear Ambitions, Washington D.C., Carnegie Endowment for International Peace.

CHUBIN, S. and LITWAK, R. S. (2003): "Debating Iran's Nuclear Aspirations", The Washington Quarterly, 26 (4): 99-104.

INSTITUTE for SCIENCE and INTERNATIONAL SECURITY (2008), "Diplomatic Offer to Iran", http://www.isis-online.org/publications /iran/Diplomatic_Offer_16June2008.pdf, (20.06. 2008).

ECONOMIST (19 March 2009), "Iran's presidential choice: It could make a big difference", http://www.economist.com/ displayStory.cfm?story_id= 13331239 . (25.03.2009).

EHTESHAMI, A. and ZWEIRI, M. (2007): Iran and the Rise of Its Neoconservatives: The Politics of Tehran's Silent Revolution. New York, I.B. Tauris.

GASIOROWSKI, M. (2007): “The New Aggressiveness in Iran's Foreign Policy", Middle East Policy, 14 (2): 125-132. 
HUNTINGTON, S. P. (1993): "The Clash of Civilizations?", Foreign Affairs, 72: 22-49.

KAMRAVA, M. (2007): "Iranian National Security Debates: Factionalism and Lost Opportunities", Middle East Policy, 14 (2): 84-100.

POLLACK, K. M. (2006): "Iran: Three Alternative Futures", Middle East Review of International Affairs, 10 (2): 73-83.

POLLACK K. M. \& TAKEYH, R. (2005): "Taking on Tehran”, Foreign Affairs, 84 (2): 20-34.

RAMAZANI, R. K. (1998): "The Shifting Premise of Iran's Foreign Policy: Toward a Democratic Peace?", Middle East Journal, 52 (2): 177-187.

SEIFZADEH, H. S. (2003): "The Landscape of Factional Politics and Its Future in Iran", Middle East Journal, 57(1): 57-75.

TAKEYH, R. (2003): "Iran at a Crossroads", Middle East Journal, 57 (1): 42-56.

TAKEYH, R. (2003): "Iran's Nuclear Calculations", World Policy Journal, 20 (2): 21-28.

TAKEYH, R. \& GVOSDEV, K. (2004): "Pragmatism in the Midst of Iranian Turmoil", The Washington Quarterly, 27 (4): 33-56.

TEHRAN TIMES (5 March 2008), "Iran: Sanctions Resolution Deals Another Blow to Security Council's Credibility", http://www.tehrantimes.com/NCms/2007.asp?code=164434, (10.03. 2008).

UN SECURITY COUNCIL REPORT (2006), http://www.securitycouncil report.org/atf/cf/\%7B65BFCF9B-6D27-4E9C-8CD3-CF6E4FF96FF 9\%7 D/Iran\%20S2006521.pdf, (12.02. 2008). 